\title{
ОБ ОЦЕНКЕ ЭФФЕКТИВНОСТИ ПРОФЕССОРСКО-ПРЕПОДАВАТЕЛЬСКОГО СОСТАВА ВЫСШЕГО УЧЕБНОГО ЗАВЕДЕНИЯ В КРИЗИСНЫХ УСЛОВИЯХ ДИСТАНЦИОННОГО ОБУЧЕНИЯ
}

\author{
(c) 2020 Минова Мария Владимировна \\ кандидат филологических наук, доцент, кафедра иностранных языков № 3 \\ Российский экономический университет им. Г. В. Плеханова, Россия, Москва \\ E-mail: Minova.MV@rea.ru \\ (C) 2020 Супрунов Семен Евгеньевич \\ старший преподаватель, кафедра иностранных языков № 3 \\ Российский экономический университет им. Г. В. Плеханова, Россия, Москва \\ E-mail:kafmkk@mail.ru \\ (c) 2020 Умарова Сабина Ибрагимовна \\ преподаватель, кафедра иностранных языков № 1 \\ Российский экономический университет им. Г. В. Плеханова, Россия, Москва \\ E-mail: Umarova.SI@rea.ru \\ () 2020 Федорова Анна Валерьевна \\ кандидат филологических наук, доцент, кафедра иностранных языков № 3 \\ Российский экономический университет им. Г. В. Плеханова, Россия, Москва \\ E-mail: Fedorova.AV@rea.ru
}

В статье авторов рассматривается вопрос, затрагивающий оценку эффективности профессорскопреподавательского состава высшего учебного заведения в кризисных условиях распространения коронавирусной инфекции, повлекшей за собой массовый переход многих субъектов на удаленный формат работы. Объектом исследования выступили высшие учебные заведения в Российской Федерации, а предметом - оценка эффективности их профессорско-преподавательского состава с поправкой на условия функционирования. Теоретическое и методологическое значение исследования заключены в развитии методов и подходов к оценке эффективности профессорскопреподавательского состава высшего учебного заведения. Практическое значение исследования определяется в формировании картины деятельности высших учебных заведений с учетом кризисных условий дистанционного обучения.

Ключевые слова: Оценка, эффективность, профессорско-преподавательский состав, высшее учебное заведение, кризис, условия, дистанционное обучение.

Мировой кризис, связанный с распространением коронавирусной инфекции, существенным образом отразился на всех без исключения сферах жизнедеятельности человека [7], включая политику, экономику, торговлю, строительство, образование (высшее, среднее и т.д.) и прочее. В результате указанного воздействия параметры функционирования обозначенных сфер значительно изменились, ввиду чего чрезвычайную актуальность приобрел вопрос их объективной оценки [5, с.77].

Исходя из того, что оценка сфер жизнедеятельности человека осуществляется, в первую очередь, на основе анализа состояния функционирующих там экономических субъектов, рас- смотрим более подробно состояние такой сферы как высшее образование [1, 2, 3].

По мнению специалистов ряда консалтинговых компаний с мировым именем одним из важнейших компонентов комплексной оценки сферы высшего образования в условиях сложившегося кризиса является оценка эффективности персонала [6, 7] его экономических субъектов (в данном случае высших учебных заведений).

Оперативные данные [6, 7] по оценке эффективности персонала высших учебных заведений в Российской Федерации в 2020 году (первые три квартала с помесячной разбивкой) приведены на рисунке 1.

Из рисунка 1 можно увидеть, что за анали- 


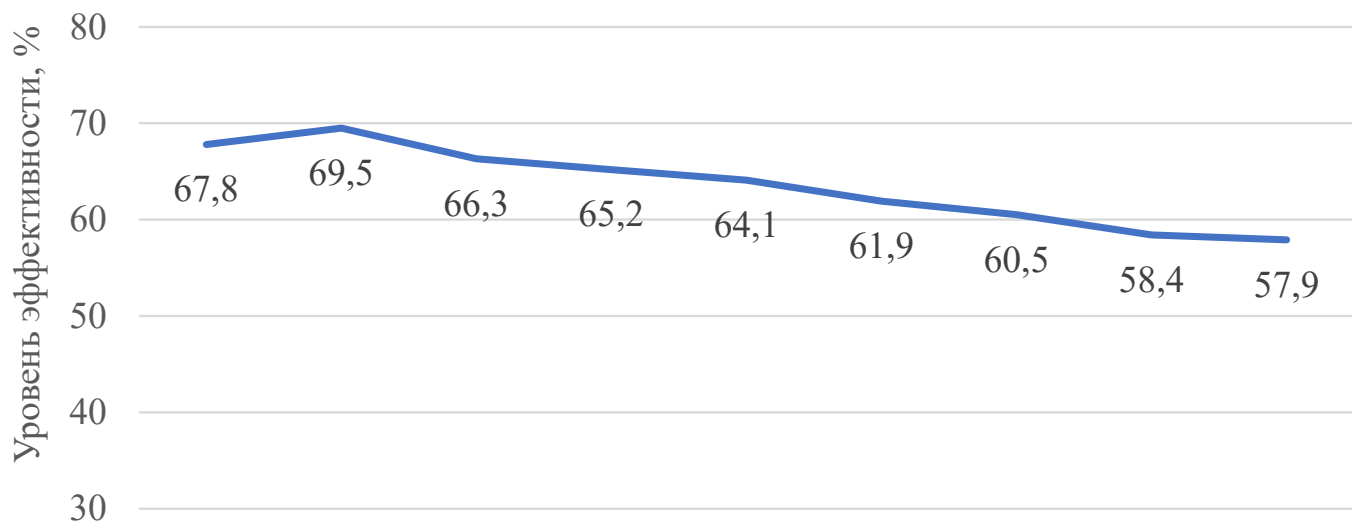

20

10

0

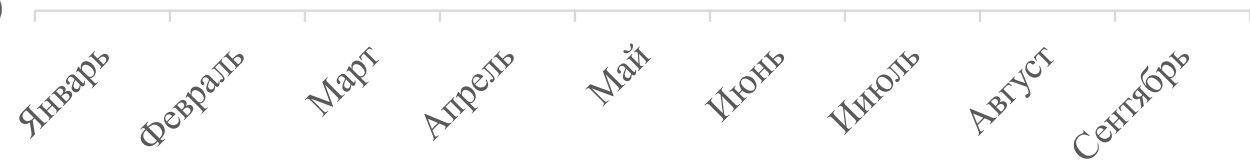

Месяц

Puc. 1. Оперативные данные по оценке эффективности персонала высших учебных заведений в Российской Федерации в 2020 году (первые три квартала с помесячной разбивкой, усредненные значения)

зируемый период времени средние значения показателя эффективности персонала высших учебных заведений в Российской Федерации уменьшились более чем на 10 процентов (с 67,8 процента в январе 2020 года до 57,9 процента в сентябре 2020 года) или в 1,17 раза. Следовательно, в целом персонал высших учебных заведений в Российской Федерации в условиях мирового кризиса, связанного с распространением коронавирусной инфекции, стал выполнять свои трудовые обязанности несколько хуже, чем обычно.

Более глубокое изучение обозначенного вопроса позволило получить локальные данные по отдельным категориям персонала в высших учебных заведениях Российской Федерации в 2020 году. Так, например, усредненные данные по оценке эффективности профессорскопреподавательского состава высших учебных заведений в Российской Федерации приведены на рисунке 2.

Данные рисунка 2 позволяют выделить четыре логических интервала в изменении анализируемого показателя в Российской Федерации за выбранный период времени:

- первый интервал: с января 2020 года по март 2020 средний уровень эффективности профессорско-преподавательского состава в высших учебных заведениях в Российской Федерации незначительно увеличился с 79,5 процентов до 81,4 процента (совокупный рост за первые три месяца 2020 года составил 1,9 процента);

- второй интервал: с марта 2020 года по май 2020 средний уровень эффективности профессорско-преподавательского состава в высших учебных заведениях в Российской Федерации значительно снизился с 81,4 процента до 76,3 процентов (совокупное снижение за второй квартал 2020 года составило порядка 5,1 процента);

- третий интервал: с мая 2020 года по июнь 2020 средний уровень эффективности профессорско-преподавательского состава в высших учебных заведениях в Российской Федерации несущественно увеличился с 76,3 процентов до 77,4 процента (совокупный рост за данный период 2020 года составил 1,1 процента); 

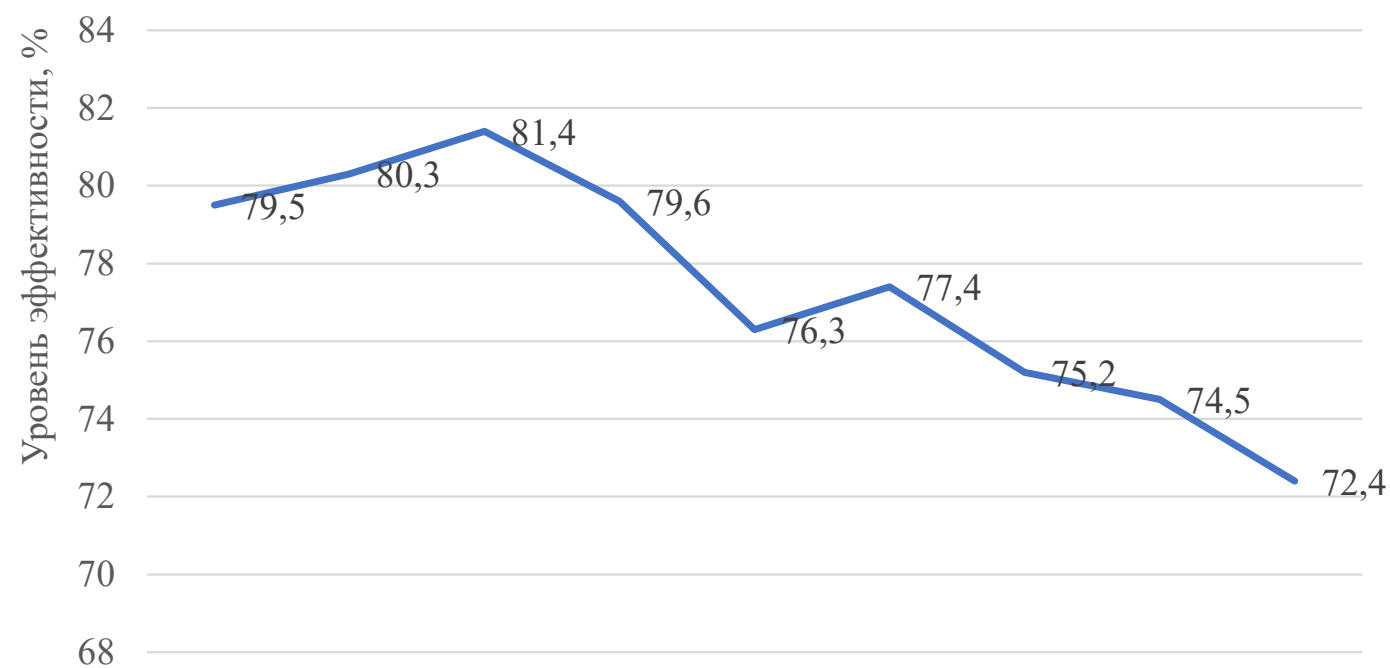

66

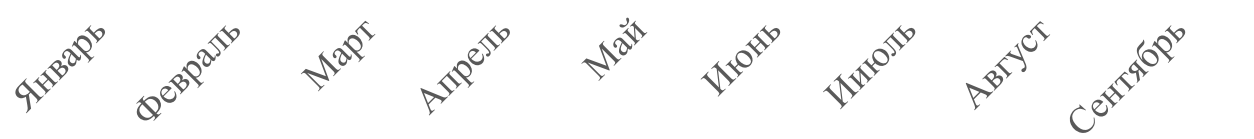

Месяц

Puc. 2. Усредненные данные по оценке эффективности профессорскопреподавательского состава высших учебных заведений в Российской Федерации в 2020 году (первые три квартала с помесячной разбивкой)

- четвертый интервал: с июня 2020 года по сентябрь 2020 средний уровень эффективности профессорско-преподавательского состава в высших учебных заведениях в Российской Федерации существенно снизился с 77,4 процентов до 72,4 процента (совокупное снижение за указанные месяца 2020 года составило 5 процентов).

В целом по рисунку 2 можно отметить, что средняя эффективность профессорскопреподавательского состава высших учебных заведений в Российской Федерации за девять месяцев 2020 года в условиях кризиса распространения коронавирусной инфекции снизилась на 7,1 процента или в 1,1 раза. Данная величина несколько меньше снижения анализируемого показателя по всему персоналу высших учебных заведений в Российской Федерации в целом.

Основные причины вызвавшие, по мнению авторов, изменение анализируемого показателя приведены в таблице 1 .

По таблице 1 поясним, что значимость причины обозначена ранговым значением (измеряется исключительно в целых положительных числах), которое изменяется от 0 (наименьшая значимость объекта исследования) до 50 (наибольшая значимость объекта исследования).
Ранги обозначенным выше причинам были проставлены экспертным путем и расположены в порядке возрастания их значимости.

В целом данные таблицы 1 позволяют сделать вывод, что изменение эффективности (в частности, общий тренд на снижение анализируемого показателя) профессорско-преподавательского состава высшего учебного заведения было вызвано комплексом причин, основанных в большей части на введении дистанционного обучения [4, с.43].

Таким образом, можно сделать вывод, что мировой кризис, связанный с распространениями коронавирусной инфекции негативным образом, отразился на эффективности функционирования всех без исключения сфер жизнедеятельности человека (от политики и экономики до медицины и образования), представленных множеством совокупностей хозяйствующих субъектов.

Так, например, в 2020 году в Российской Федерации значительно снизилась эффективность высших учебных заведений в целом и персонала (в том числе профессорско-преподавательского состава с 79,5 процентов в январе месяце до 72,4 процентов в сентябре месяце), в частности. 
Таблица 1. Основные причины вызвавшие, по мнению авторов, изменение эффективности профессорско-преподавательского состава высших учебных заведений в Российской Федерации в 2020 году

\begin{tabular}{|c|c|c|}
\hline Причина & Характеристика причины & $\begin{array}{c}\text { Значимость, } \\
\text { ед. }(0-50)\end{array}$ \\
\hline $\begin{array}{l}\text { Перевод части процесса обуче- } \\
\text { ния на дистанционный формат }\end{array}$ & $\begin{array}{l}\text { Суть данной причины заключена в существенных изменени- } \\
\text { ях работы высшего учебного заведения по формату взаимо- } \\
\text { действия преподавателя и студента }\end{array}$ & 20 \\
\hline $\begin{array}{l}\text { Недостаточная готовность ма- } \\
\text { териальной базы высших учеб- } \\
\text { ных заведений и студентов }\end{array}$ & $\begin{array}{l}\text { Суть данной причины заключена в недостаточной готовно- } \\
\text { сти (в первую очередь в техническом плане) преподавателей } \\
\text { и студентов к обучению с акцентом на новый формат }\end{array}$ & 10 \\
\hline $\begin{array}{l}\text { Недостаточное соответствие } \\
\text { методической базы высшего } \\
\text { учебного заведения сложив- } \\
\text { шимся условиям }\end{array}$ & $\begin{array}{l}\text { Суть данной причины заключена в недостаточной готовно- } \\
\text { сти (в первую очередь в методическом и методологическом } \\
\text { плане) преподавателей и студентов к обучению с акцентов на } \\
\text { новый формат }\end{array}$ & 10 \\
\hline $\begin{array}{l}\text { Снижение заинтересованности } \\
\text { студентов в результативности } \\
\text { процесса обучения }\end{array}$ & $\begin{array}{l}\text { Суть данной проблемы заключена в существенном снижении } \\
\text { мотивации студентов к получению новых знаний }\end{array}$ & 5 \\
\hline $\begin{array}{l}\text { Снижение эффективности кон- } \\
\text { троля за работой студентов }\end{array}$ & $\begin{array}{l}\text { Суть данной проблемы состоит в значительном снижении } \\
\text { контроля (в первую очередь текущего) за процессом обуче- } \\
\text { ния в дистанционном формате }\end{array}$ & 5 \\
\hline
\end{tabular}

Основными причинами повлиявшими, на наш взгляд, на возникновение данного момента в Российской Федерации за анализируемый период времени стали: перевод части процесса обучения на дистанционный формат (основной ранг значимости, равный 20 единицам из 50 возможных); недостаточная готовность ма- териальной базы высших учебных заведений и студентов; недостаточное соответствие методической базы высшего учебного заведения сложившимся условиям; снижение заинтересованности студентов в результативности процесса обучения и снижение эффективности контроля за работой студентов.

\section{Библиографический список}

1. Акбаева Х.Б. Дистанционное обучение как эффективная форма обучения иностранному языку / Х.Б. Акбаева // Мировая наука - Саратов: Изд-во «ООО «Институт управления и социально-экономического развития», 2020. - № 4.- С. 138-139.

2. Малянов Д.В. Проблемы повышения качества образования в контексте повышения эффективности деятельности вузов / Д.В.Малянов // Экономические науки - Москва: Изд-во: «ООО «24 Принт», 2019.№ $10 .-$ С. $82-85$.

3. Пруцких А.А. Управление персоналом образовательной организации: особенности, проблемы и задачи / А.А.Пруцких // Международный научно-исследовательский журнал - Екатеринбург: Изд-во: «Соколова Марина Владимировна», 2019. - № 3.- С. 114-116.

4. Романова М.Н., ФилипповаС.Ф. Дистанционное обучение студентов очного обучения / М.Н. Романова, С.Ф.Филиппова // Современное образование: традиции и инновации - Санкт-Петербург: Изд-во: «ОоО «НИЦ АРТ», 2020. - № 3.- С. 41-44.

5. Черноусов А.А., Вавилова Е.В. Оценка внешних эффектов распространения высшего образования в российских условиях / А.А. Черноусов, Е. В. Вавилова // Открытое образование - Москва: Изд-во: «Российский экономический университет имени Г. В.Плеханова», 2019.- № 1.- С. 76-85.

6. Компания «Федеральная служба государственной статистики» [Электронный ресурс]: аналитические материалы - Официальный сайт компании «Федеральная служба государственной статистики», 2020.- Режим доступа: https://rosstat.gov.ru/

7. Компания «SCHNEIDER GROUP» [Электронный ресурс]: аналитические материалы - Официальный сайт компании «SCHNEIDER GROUP», 2020.- Режим доступа: https://schneider-group.com/ru/ 